J. Clin. Chem. Clin. Biochem:

Vol. 21, 1983, pp. 611-614

\title{
An Economical Assay for HDL Phosphatidyl Choline
}

\author{
By H. Schriewer, G.Jung, F. Emke and G. Assmann
}

Zentrallaboratorium der Medizinischen Einrichtungen der Westfälischen Wilhelms-Universität Münster

(Received February 11/May 9, 1983)

Herrn Prof. Dr. H. M. Rauen zum siebzigsten Geburistag gewidmet

Summary: An economical enzymatic assay for HDL phosphatidyl choline is described, as adapted for the Cobas-Bio analyser (Hoffmann LaRoche). This method entails the enzymatic cleavage of phosphatidyl choline by phospholipase $C$ from B.cereus, hydrolysis of phosphoryl choline and enzymatic determination of choline with choline oxidase by an enzymatic colour test. This method provides consistent values and is, by comparison to the enzymatic UV method (assaying choline with choline kinase in an optical test procedure), simpler to perform, more precise, and less expensive.

\section{Eine rationelle Methode zur Bestimmung von HDL-Phosphatidylcholin}

Zusammenfassung: Es wird eine rationelle enzymatische Bestimmungsmethode von HDL-Phosphatidylcholin beschrieben, die an den Analysator Cobas-Bio (Hoffmann LaRoche) adaptiert wurde. Das Prinzip dieser Methode besteht in der enzymatischen Spaltung von Phosphatidylcholin mittels Phospholipase C aus B.cereus und der enzymatischen Bestimmung von Cholin mittels Cholinoxidase in einem enzymatischen Farbtest nach Hydrolyse von Phosphorylcholin. Das Verfahren liefert im Vergleich zur enzymatischen UV-Methode (Messung von Cholin mittels Cholinkinase im optischen Test) übereinstimmende Werte und ist im Vergleich zur enzymatischen UV-Methode einfacher durchführbar, präziser und billiger.

\section{Introduction}

It has been shown in epidemiological $(1-5)$ and clinical $(6,7)$ studies that HDL cholesterol represents a risk indicator for coronary heart disease. HDL, however, do not constitute a single substance, but comprise a heterogeneous mixture of macromolecules of various composition, metabolism, and physicochemical properties. Only after the additional determination of other HDL components, such as HDL apolipoproteins or HDL phospholipids, is it possible to gain any information regarding HDL composition or HDL mass:

This group recently reported on an enzymatic method for determining HDL phosphatidyl choline (8). The principle of the method involves the specific cleavage of phosphatidyl choline by phospholipase $C$ from B.cereus, followed by enzymatic determination of choline hydrolysed from phosphorylcholine by choline kinase, as detected by an optical method. Al- though the newly proposed enzymatic method is less laborious and more precise than the previously employed conventional chemical method, it involves various disadvantages including relatively high cost of analysis, relatively low processing rate $(20-30$ samples/day in duplicate) and poor automation capability.

In the following we report a modification of the enzymatic HDL phosphatidyl choline assay, which we have adapted for use with the Cobas-Bio centrifugal analyser (Hoffmann LaRoche).

\section{Materials and Methods}

Phosphotungstic acid $/ \mathrm{MgCl}_{2}$ precipitation reagent Boehringer Mannheim, Order No. 400971.

Phospholipase C from B.cereus (EC 3.1.4.3)

Boehringer Mannheim, Order No. 241709

(phospholipase $C$ diluted to $90 \mathrm{kU} /$ with $3.2 \mathrm{mmo} / \mathrm{h}$ ammonium sulphate solution). 
Alkaline phosphatase (EC 3.1.3.1), specific activity $140 \mathrm{U} / \mathrm{mg}$ Boehringer Mannheim, Order No. 108162.

Choline oxidasc from Arthrobacter globiformis (EC 1.1.3.17), specific activity $10 \mathrm{U} / \mathrm{mg}$ protein

Boehringer Mannheim, Order No. 430323.

Monotest cholesterol 'High Performance', CHOD-PAP method Boehringer Mannheim, Order No. 237574.

\section{Sample material}

We used samples of the serum collected for the 'Prospective epidemiological study of company employees in Westfalia' reported elsewhere (8).

\section{Methods}

\section{HDL isolation}

HDL was isolated by ultracentrifugation or by precipitation of apolipoprotein B-containing lipoproteins with phosphotungstic acid $/ \mathrm{MgCl}_{2}$, as described in detail elsewhere (9).

\section{Enzymatic determination of HDL phosphatidyl choline}

Choline kinase method: This method is described in detail elsewhere (8).

Choline oxidase method: The assay of phosphatidyl choline by the choline oxidase method was performed on the Cobas-Bio centrifugal analyser (Hoffmann LaRoche) according to the following sequence:

Phosphatidyl choline $\stackrel{\text { phospholipase } C}{\longrightarrow}$ phosphorylcholine + diglycerides

Phosphorylcholine $\stackrel{\text { alkaline phosphatase }}{\longrightarrow}$ choline + phosphate

Choline $+\mathrm{O}_{2} \stackrel{\text { choline oxidase }}{\longrightarrow}$ betaine $+\mathrm{H}_{2} \mathrm{O}_{2}$

$2 \mathrm{H}_{2} \mathrm{O}_{2}+$ phenol +4 -amino-antipyrine $\stackrel{\text { peroxidase }}{\longrightarrow} 4$ - $(p$-benzo quinonemonoamino)-phenazone $+\mathrm{H}_{2} \mathrm{O}$

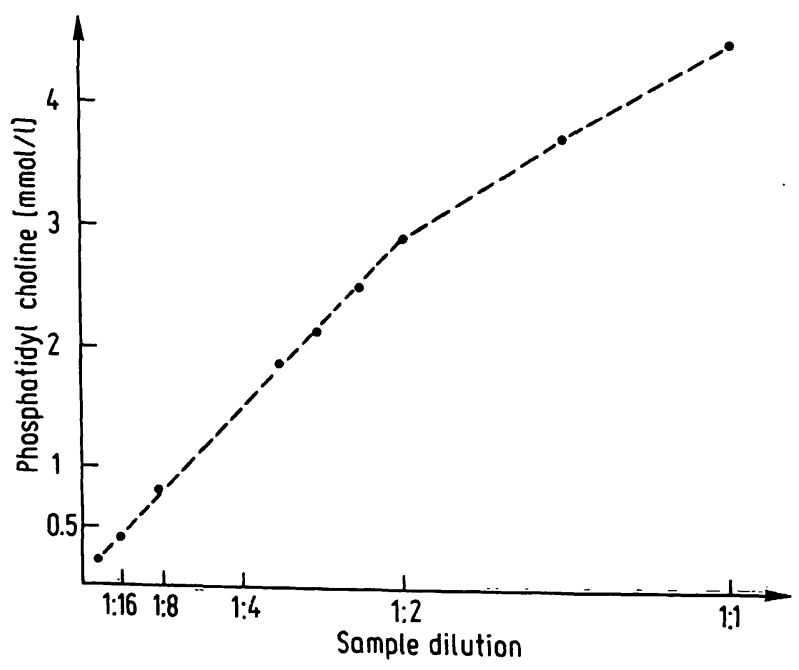

Fig. 1. Measured phosphatidyl choline values as a function of the amount of sample used. Special control serum for HDL cholesterol (Boehringer Mannheim, Lot. No. 1-201) was dissolved with one-fourth the given volume of water $(1: 1)$ and diluted $1: 2,1: 4,1: 8,1: 16$. The assay was run in duplicate.
The reagent solutions were freshly prepared in the following manner:

$$
\begin{aligned}
& \text { reaction solution } A-10 \mathrm{ml} \text { monotest cholesterol } \\
& \text { - 500 } \mu \mathrm{l} \text { phospholipase C (90 kU/l) } \\
& \text { - } 50 \mu \mathrm{l} \text { alkaline phosphatase }(1400 \mathrm{kU} / \mathrm{l}) \\
& \text { start reagent B }-100 \mu \mathrm{l} \text { choline oxidase }(50 \mathrm{kU} / \mathrm{l}) \\
& \text { - } 500 \mu \mathrm{l} \mathrm{NaCl} \text {-solution }(0.15 \mathrm{~mol} / \mathrm{l})
\end{aligned}
$$

$3 \mu \mathrm{l}$ sample were mixed with $300 \mu \mathrm{l}$ solution $\mathrm{A}$ and incubated at $37^{\circ} \mathrm{C}$ for 15 minutes. The absorbance of this mixture at $500 \mathrm{~nm}$ was recorded. Exactly 7.0 minutes after addition of $10 \mu \mathrm{l}$ of the start reagent $B$, absorbance at $500 \mathrm{~nm}$ was recorded again, keeping the temperature at $37^{\circ} \mathrm{C}$. Calculation was made on the basis of the difference in absorbance $\Delta \mathrm{A}$ with respect to a choline standard. The concentration of the choline standard was determined gravimetrically and by means of the choline kinase method (8).

The parameter list for the Cobas Bio was as follows:

$\begin{aligned} 1 & \text { Units } \\ 2 \text { Calculation factor } & 0 \\ 3 \text { Standard 1 conc } & \\ 4 \text { Standard 2 conc } & \text { chol } \\ 5 \text { Standard 3 coñc } & \\ 6 \text { Limit } & 0 \\ 7 \text { Temperature (Deg. C) } & 37 \\ 8 \text { Type of analysis } & 6 \\ 9 \text { Wavelength (nm) } & 500 \\ 10 \text { Sample volume }(\mu \mathrm{l}) & 3 \\ 11 \text { Diluent volume }(\mu \mathrm{l}) & 10 \\ 12 \text { Reagent volume }(\mu \mathrm{l}) & 300 \\ 13 \text { Incubation time (sec.) } & 900 \\ 14 \text { Start reagent volume ( } \mu \mathrm{l}) & 10 \\ 15 \text { Time of first reading (sec.) } & 3 \\ 16 \text { Time interval (sec.) } & 30 \\ 17 \text { Number of readings } & 15 \\ 18 \text { Blanking mode } & 1 \\ 19 \text { Printout mode } & 1\end{aligned}$

\section{Results}

\section{Course of reaction}

The choline oxidase activity in the test solution was chosen so that the indicator reaction (formation of 4( $p$-benzoquinonemonoamino)-phenażone) did not run to completion within the incubation period. Under the given conditions the increase in extinction time was constant over the measurement period, which was selècted at 7.0 minutes.

\section{Linearity}

In order to determine the linearity, a solution of lyophilised control serum was made with one-fourth the original water content, a dilution series was made, and phosphatidyl choline content was determined in the samples prepared. The measured values were proportional to the sample dilution within the range tested $(0.17 \mathrm{mmol} / \mathrm{l}-2.73 \mathrm{mmol} / \mathrm{l})$ (fig. 1$)$. 


\section{Accuracy}

Comparison of the HDL phosphatidyl choline values obtained with the choline oxidase and choline kinase methods showed good correspondence of results $(r=0.9779, y=0.9396 x+0.0577, n=32)$.

Regression analysis of the data of the apolipoprotein B-free supernatant as well as of the $d>1.063 \mathrm{~kg} /$ fraction isolated by ultracentrifugation also indicated that the phosphatidyl choline values obtained with the choline oxidase method from the apolipoprotein B-free supernatant corresponded well with the phosphatidyl choline values for HDL fractions isolated by ultracentrifugation $(\mathrm{r}=0.97, \mathrm{y}=0.89 \mathrm{x}+0.12, \mathrm{n}=$ 90) (fig. 2).

\section{Precision}

Precision of the series was represented by a coefficient of variation of $2.8 \%(\bar{x}=0.993 \mathrm{mmol} / \mathrm{h}, \mathrm{n}=$ 10). Day-to-day precision was determined with serum samples taken from a fresh serum pool and stored in aliquots at $-20^{\circ} \mathrm{C}$. The coefficient of variation for day-to-day precision was $5.49 \%(\overline{\mathrm{x}}=1.012$ $\mathrm{mmol} / \mathrm{l}, \mathrm{n}=19$ ).

\section{Discussion}

Routine assay of phospholipids without undue effort has been possible since the advent of commercially available phospholipases with specific cleavage properties. The phosphatidyl choline assay recently described by us (8) entails the specific cleavage of phosphatidyl choline into diglycerides and phosphorylcholine by phospholipase $\mathrm{C}$, hydrolytic cleavage of phosphorylcholine with alkaline phosphatase, followed by enzymatic determination of choline with choline kinase, using an optical test (UV method).

Substantial drawbacks to the UV method are, however, the high cost of analysis, relatively low processing rate (approx. 20-30 samples/day in duplicate), and difficulties associated with automation of the method.

The improved method described here is distinguished from the UV method by the change in indicator reaction, in which choline is converted by choline oxidase in an enzymatic colour test. In order to conserve choline oxidase, the reaction may be recorded with fixed-time kinetics. Prerequisites are linearity of the reaction within the measuring period

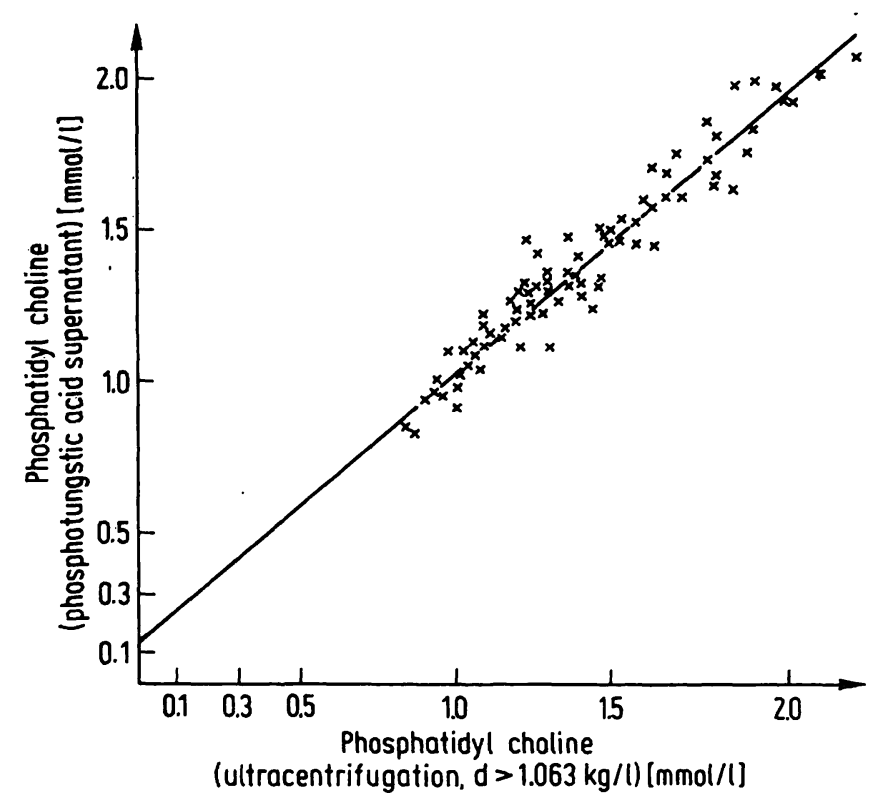

Fig. 2. Regression analysis of HDL phosphatidyl choline values obtained from the $d>1.063 \mathrm{~kg} / \mathrm{HDL}$ fraction isolated by ultracentrifugation $(x)$ and from the supernatant following phosphotungstic acid $/ \mathrm{MgCl}_{2}$ precipitation $(y) . r=0.97$, $\mathrm{y}=0.89 \mathrm{x}+0.12, \mathrm{n}=90$.

and complete cleavage of phosphatidyl choline during the pre-incubation period, which we established by thin-layer chromatography of the lipid extract subsequent to phospholipase $\mathrm{C}$ and alkaline phosphatase action. We used an aqueous choline standard as a reference. We believe the use of micellar phosphatidyl choline is problematic, since phosphatidyl choline is then present in a physicochemical form completely different from that in native serum, the apolipoprotein B-free supernatant, or the HDL fraction isolated by ultracentrifugation.

The assay of phosphatidyl choline in the apolipoprotein B-free supernatant (HDL phosphatidyl choline) was adapted by us for use with the Cobas-Bio centrifugal analyser. This is a simplification which provides for a significant improvement in precision of the method and a reduction in reagent costs. Use of the commercial cholesterol monotest renders superfluous the preparation of reagents for the choline assay, but further reduction in reagent costs may be achieved by mixing one's own reagents. The phosphatidyl choline assay started by choline oxidase is not influenced by the reagent for cholesterol determination, since the colour reaction for all of the cholesterol is complete by the end of the preincubation period. The data obtained with the enzymatic colour test on the Cobas-Bio analyser correlates well with the HDL phosphatidyl choline values obtained man- 
ually with the UV method. In view of the close correlation of the values from the UV method with those obtained by the conventional chemical method (8), the present study does not include a comparison between data from the enzymatic colour test and the chemical method. The results of this study also indicate a close correlation of phosphatidyl choline

\section{References}

1. Miller, G. J. \& Miller, N.E. (1975) Lancet $I, 16-19$.

2. Rhoads, G. G., Gulbrandsen, C. L. \& Kagan, A. (1976) New Engl. J. Med. 294, 293-298.

3. Berg, K., Børresen, A. \& Dahlén G. (1976) Lancet $I$, 499502.

4. Castelli, W. P., Doyle, J. T., Gordon, T., Hames, C. G., Hjortland, M. C., Hulley, S. B., Kagan, A. \& Zukel, W. J. (1977) Circulation 55, 767-772.

5. Gordon, T., Castelli, W. P., Hjortland, M. C., Kannel, W. B. \& Dawber, T. R. (1977) Ann. Int. Med. 87, 393-397. values between the apolipoprotein B-free supernatant and the $d>1.063 \mathrm{~kg} /$ fraction isolated by ultracentrifugation.

\section{Acknowledgement}

Supported by the Deutsche Forschungsgemeinschaft.

6. Barboriak, J. J., Anderson, A. J., Rimm, A. A. \& King, J. F. (1979) Metabolism 28, 735-738.

7. Kladetzky, R. G., Assmann, G., Walgenbach, S., Tauchert, P. \& Helb, H.-D. (1980) Artery 7, 191-205.

8. Schriewer, H., Jabs, H.-U., Günnewig, V. \& Assmannn, G. (1983) J. Clin. Chem. Clin. Biochem. 21, 145-150.

9. Schriewer, H., Jabs, H.-U. \& Assmann, G. (1982) J. Clin. Chem. Clin. Biochem. 20, 305-312.

Professor Dr. H. Schriewer

Zentrallaboiratorium

der Medizinischen Einrichtungen

Westfälische Wilhelms-Universität

Albert-Schweitzer-Str. 33

D-4400 Münster 